\title{
Excess ${ }^{182} \mathrm{~W}$ preserved in Archean crust from the Yilgarn Craton, Western Australia
}

\author{
D. StUBbS ${ }^{1 *}$, A. I. S. KemP ${ }^{2}$, T. ElliotT ${ }^{1}$ \\ ${ }^{1}$ School of Earth Sciences, University of Bristol, BS8 1RJ, \\ UK (*correspondence: ds13316@bristol.ac.uk) \\ ${ }^{2}$ School of Earth Sciences, The University of Western \\ Australia, Perth, Australia
}

Almost a decade on from its first discovery [1], it is now well documented that several Archean terranes preserve excesses in radiogenic ${ }^{182} \mathrm{~W}$ relative to the modern upper mantle. Owing to the $8.9 \mathrm{Ma}$ half life of the parental isotope ${ }^{182} \mathrm{Hf}$, such variability requires the formation of reservoirs with distinct ${ }^{182} \mathrm{~W}$ compositions within $\sim 50$ Ma of solar system history. That some of the oldest preserved terrestrial material and the modern mantle are distinct requires the admixture of at least two of these disparate components over Earth's history. Two obvious questions arise; (a) what were these reservoirs?, and (b) how long did it take for them to $\operatorname{mix}$ ?

The answers to (a) remain controversial, but variably cite a role for early silicate differentiation [2], the addition of extra-terrestrial material [1], or admixture of material from the core [3]. We instead focus on the latter question, specifically trying to find a transition from Archean-like ${ }^{182} \mathrm{~W}$ excesses to modern mantle compositions in a single craton. We chose the Narryer Terrane of the Yilgarn Craton, Western Australia, as it preserves material ranging from the Eoarchean to Neoarchean, and contains both mafic and felsic lithologies.

We have measured $\mathrm{W}$ concentrations and isotopic compositions of a range of lithologies including TTG gneisses, leucogabbros, and granites. Tungsten concentrations range from 2 to $3200 \mathrm{ppb}$, with some granulite facies TTG gneisses having the lowest concentrations, suggesting secondary mobility of $\mathrm{W}$ in the terrane. TTG gneisses at $\sim 3700, \sim 3500$, and $\sim 3300$ Ma preserve ca. $10 \mathrm{ppm}{ }^{182} \mathrm{~W}$ excesses, along with $\sim 3740$ Ma gabbroic remnants from the Manfred Complex. Younger 2650 Ma granites also contain similar excesses, but may be influenced by the incorporation of older crust [4]. To see whether more juvenile input to the craton in the late Archean is also anomalous for W, further mafic lithologies are being investigated.

[1] Willbold M. et al (2011) Nature 473 (195-198). [2] Touboul M. et al (2012) Science 335 (1065-1069). [3] Rizo H. et al (2019) Geochem Persp. Let 11 (6-11). [4] Kemp A. et al (2010) EPSL 296 (45-56). 